\title{
Bioethanol Production From Pineapple Wastes
}

\author{
Alessia Tropea ${ }^{1,2}$, David Wilson ${ }^{1}$, Loredana G. La Torre ${ }^{2}$, Rosario B. Lo Curto ${ }^{2}$, Peter Saugman ${ }^{3}$, \\ Peter Troy-Davies ${ }^{4}$, Giacomo Dugo ${ }^{2} \&$ Keith W. Waldron ${ }^{1}$ \\ ${ }^{1}$ Institute of Food Research, Colney, Norwich, NR4 7UA, UK \\ ${ }^{2}$ S.A.S.T.A.S (Dipartimento di Scienze dell'Ambiente, della Sicurezza, del Territorio, degli Alimenti e della \\ Salute), University of Messina, Viale F. Stagno d'Alcontres, Messina, Italy \\ ${ }^{3}$ PBI S. A. (Costa Rica,) c/o Fernandez Zeledón y Asociados, 200 M este, 100 M sur del Banco Nacional San \\ Pedro de Montes de Oca San José Costa Rica \\ ${ }^{4}$ CIP.S A, The Old Library, 30 Dock Street, Fleetwood, FY7 6AG, UK \\ Correspondence: Keith W. Waldron, Institute of Food Research, Norwich Research Park, Colney, Norwich NR4 \\ 7UA, UK. Tel: 44-1603-255-385. E-mail: keith.waldron@ifr.ac.uk
}

Received: June 10, 2013 Accepted: December 10, 2013 Online Published: April 15, 2014

doi:10.5539/jfr.v3n4p60 URL: http://dx.doi.org/10.5539/jfr.v3n4p60

\begin{abstract}
There is great interest in producing bioethanol from biomass and there is much emphasis on exploiting lignocellulose sources, from crop wastes through to energy-rich crops. Some waste streams, however, contain both cellulosic and non-cellulosic sugars. These include wastes from pineapple processing.

Pineapple wastes are produced in large amounts throughout the world by canning industries. These wastes are rich in intracellular sugars and plant cell walls which are composed mainly of cellulose, pectic substances and hemicelluloses. The purpose of this study was to investigate the potential to transform such residues into ethanol after enzymatic saccharification of plant cell walls, and fermentation of the resulting simple sugars using the Saccharomyces cerevisiae NCYC 2826 strain. Three different fermentation modes, direct fermentation, separate hydrolysis and fermentation, and simultaneous saccharification and fermentation of the biomass were tested and compared. The results show that the main sugars obtained from pineapple waste were: glucose, uronic acid, xylose, galactose, arabinose and mannose. The highest ethanol yield was achieved after 30 hours of simultaneous saccharification and fermentation, and reached up to $3.9 \%(\mathrm{v} / \mathrm{v})$, corresponding to the $96 \%$ of the theoretical yield.
\end{abstract}

Keywords: ethanol production, pineapple waste, Saccharomyces cerevisiae, simultaneous saccharification and fermentation, fermentation

\section{Introduction}

Due to the rapid depletion of the world's energy supply, there is an increasing global interest in alternative energy sources (Lin \& Tanaka, 2006). Ethanol from biomass can provide a sustainable, albeit limited alternative to oil to mitigate the global energy problem associated with fossil fuels exhaustion and greenhouse gas emissions (Farrell et al., 2006). Currently, biomass-derived ethanol is produced at industrial scale from sucrose and starch; however, this poses concerns about the potential competition with food and feed supplies (Hahn-Hägerdal, Galbe, Gorwa-Grauslund, Lidén, \& Zacchi, 2006; Field, Campbell, \& Lobell, 2008). In addition, the conversion of forest and grassland into new cropland to supply an increasing demand for biomass is also problematic because such land-use changes increase greenhouse gas emissions (Farrell et al., 2006; Searchinger et al., 2008). Hence, other alternatives such as the production on fallow fields of crops and grasses to produce biofuels have recently attracted attention. In particular, the lignocellulosic materials such as agricultural wastes are considered to be the main potential sources of biomass for "second generation" bioethanol production (Galbe \& Zacchi, 2007; Merino \& Cherry, 2007; Sakai et al., 2007; Hu, Heitmann, \& Rojas, 2008; Goh, Tan, Lee, \& Bhatia 2010).

Pineapple wastes (PW) comprise fruit trimmings produced in large amounts by canning industries throughout the world (FAO, 2009). Costa Rica is among the main producers and exporters, with approximately 110,000 acres of pineapples. Approximately $25 \%$ of the fresh pineapple harvested in Costas Rica is processed to make added value products such as concentrated juice, jelly and canned pineapple. Nearly $75 \%$ of the fruit processed in 
canneries results in peeled skin, core, crown end, etc., which is not utilized and generally discharged as a waste. The dry matter content in pineapple waste is around $10 \%$, and composed of about $96 \%$ organic and $4 \%$ inorganic matter (Abdullah, 2007). These materials exhibit both high biochemical oxygen demand (BOD) and chemical oxygen demand (COD) values (Ban-Koffi \& Han, 1990), and give rise to serious pollution problems if not properly disposed of.

In the past, PW were utilized as sources for bromelin extraction, wine and vinegar production, yeast cultivation for food/feed proteins, or also for organic acids production (Larrauri, Ruperez, \& Calixto, 1997; Nigam, 1999a, b; Busairi, 2008; Hebbar, Sumana, \& Raghavarao, 2008; Dacera, Babel, \& Parkpian, 2009; Jamal, Fahrurrazi, \& Zahangir, 2009; Banik, Nag, \& Debnath, 2011; Dhanasekaran, Lawanya, Saha, Thajuddin, \& Panneerselvam, 2011; Raji, Jibril, Misau, \& Danjuma, 2012). The high sugar and lignocellulosics amounts found in PW provide a potentially interesting source of valuable fermentation and non-fermentation products. Lignocellulose comprises two main classes of structural polysaccharides, cellulose and hemicellulose. If hydrolysed, they can provide sources of fermentable sugars (glucose and xylose, respectively). The polysaccharides, however, are tightly packed in plant cell walls and are often surrounded by lignin, forming highly recalcitrant structures resistant to direct enzymatic attack (Sun \& Cheng, 2002; Himmel et al., 2007). Cellulose and hemicellulose fractions from agroindustrial residues can be depolymerized to fermentable sugars giving rise respectively to hexoses (glucose and mannose) and pentoses (xylose and arabinose), either by enzymatic or chemical hydrolyses (Sun \& Cheng, 2002; Mosier et al., 2005; Himmel et al., 2007).

Enzymatic hydrolysis is regarded today as the most promising approach to liberating fermentable sugars in an energy-efficient way from the carbohydrates found in lignocellulosics in order to produce ethanol (Wooley, Ruth, Glassner, \& Sheehan, 1999; Galbe \& Zacchi, 2002; Yu \& Zhang, 2004). Sugars released by enzymes then can be fermented to ethanol by yeasts. There are several fermentation approaches that can be considered. Sequential enzymatic hydrolysis and fermentation are described as separate hydrolysis and fermentation (SHF), while when the two steps are simultaneously carried out, the process is called simultaneous saccharification and fermentation (SSF). SSF has the advantage of preventing the buildup of hydrolysis products such as cellobiose and glucose, which can reduce the rate of further substrate hydrolysis. However, it has to be carried out at temperatures that suit the fermenting organism. In the case of yeast, the temperature is generally below $40{ }^{\circ} \mathrm{C}$, which is below the optimum temperature for enzymatic hydrolysis $\left(50^{\circ} \mathrm{C}\right)$ (Takagi, Abe, Suzuki, Emert, \& Yata, 1977; Tengborg, Galbe, \& Zacchi, 2001). Fermentation also seems to decrease the inhibition of the enzymes probably by converting some of the toxic compounds present in the hydrolysate (Tengborg et al., 2001). These mechanisms increase the overall productivity, the concentration and also the final ethanol yield (Wright, Wyman, \& Grohmann, 1988; Philippidis, Smith, \& Wyman, 1993; Soderstrom, Galbe, \& Zacchi, 2005).

In this study three different processes were used to obtain bioethanol from PW: direct fermentation (DF) followed by enzyme addition to verify the real yeast capacity of fermenting the untreated substrate; separate hydrolysis and fermentation (SHF) in the same reactor; simultaneous saccharification and fermentation (SSF).

\section{Materials and Methods}

\subsection{Substrate}

Pineapples were obtained from a local market in Norwich, UK. For analytical purpose, the pineapple was divided into four parts: crown (the top part), skin, pulp and core (the inner part). In this study only skin and core were used for fermentation tests.

\subsection{Yeasts}

Saccharomyces cerevisiae NCYC 2826 was provided by National Collection of Yeast Cultures, a BBSRC-supported National Capability based at the Institute of Food Research, Norwich The strain was maintained on YM agar medium (yeast extract $3 \mathrm{~g} / \mathrm{L}$, malt extract $3 \mathrm{~g} / \mathrm{L}$, peptone $5 \mathrm{~g} / \mathrm{L}$, glucose $10 \mathrm{~g} / \mathrm{L}$ ) at $4{ }^{\circ} \mathrm{C}$. To carry-out the tests $S$. cerevisiae was grown overnight at $30{ }^{\circ} \mathrm{C}$ on a rotary shaker (INNOVA 44, Incubator Shaker Series, New Brunswick Scientific) at $200 \mathrm{rpm}$, in tubes containing $20 \mathrm{ml}$ YM medium.

\subsection{Experimental Set-up}

Fermentation tests were carried out in a $2.5 \mathrm{~L}$ batch fermenter (LH Fermentation 2000 Series). The fermenter was equipped with one four-bladed rushton turbine, and the common control systems: temperature, $\mathrm{pH}, \mathrm{CO}_{2}$ detector and gas mass flow meter.

Pineapple wastes, comprising fruit skin and core, were homogenized in a fruit blender. The resulting homogenate, with a dry matter content of $14 \%(\mathrm{w} / \mathrm{w})$, was diluted with water to a $9 \%$ dry matter, in a working volume of $1.5 \mathrm{~L}$ and immediately treated at $100{ }^{\circ} \mathrm{C}$ for 10 min under continuous mixing to inactivate endogenous enzymes and 
reduce microbial spoilage. No further sterilization procedure was adopted.

Three different processes were used to obtain bioethanol: direct fermentation (DF) of the blended biomass followed by enzyme addition; separate hydrolysis and fermentation (SHF); simultaneous saccharification and fermentation (SSF).

For DF of the blended biomass, with a dry matter content of $9.2 \%, 20 \mathrm{ml}$ of $S$. cerevisiae inoculum $\left(10^{7}\right.$ cells per $\mathrm{ml}$ ) were added to the medium. The tests were carried out at $30^{\circ} \mathrm{C}$ under continuous mixing at $200 \mathrm{rpm}$. $\mathrm{pH}$ was previously adjusted from 3.8 up to 4.5 using $2 \mathrm{M} \mathrm{NaOH}$.

After 12 hours the medium was supplemented with $20 \mu \mathrm{l} / \mathrm{g}$ dry matter of Depol ${ }^{\mathrm{TM}} 740 \mathrm{~L}$ and $250 \mu \mathrm{l} / \mathrm{g}$ dry matter of Accellerase ${ }^{\circledR} 1500$ enzymes, maintaining the same fermentation parameters.

For SHF fermentations, saccharification of $8.5 \%$ dry matter biomass, was carried out using the same cell-wall degrading enzymes, as above, for $2 \mathrm{~h}$ at $50{ }^{\circ} \mathrm{C}$ and $\mathrm{pH} 5$, adjusted using $\mathrm{NaOH} 2 \mathrm{M}$, with constant stirring at 500 rpm. After 6 hours digested substrate was cooled to $30^{\circ} \mathrm{C}$ and stirring decreased to $200 \mathrm{rpm}$. pH at 4.5 was not further corrected by alkali addition. The fermentation started with addition of $20 \mathrm{ml}$ of $S$. cerevisiae inoculum, as before.

SSF fermentation was carried out adding together enzymes and yeast culture to the substrate. Fermentation parameters were $30^{\circ} \mathrm{C}, \mathrm{pH} 4.5$, adjusted as above, and constant stirring at $200 \mathrm{rpm}$. Initial biomass dry matter was $9 \%$.

$\mathrm{CO}_{2}$ evolution was measured during all fermentation tests using a ADC Infra Red $\mathrm{CO}_{2}$ Analyzer and duplicate broth samples were withdrawn from the reaction vessel using a $20 \mathrm{ml}$ syringe: the sample for ethanol analysis was immediately frozen at $-18{ }^{\circ} \mathrm{C}$ until analysis; whereas samples for moisture determination, soluble and insoluble sugars were heated at $100{ }^{\circ} \mathrm{C}$ for $6 \mathrm{~min}$ to inactivate the enzymes and then frozen at $-18{ }^{\circ} \mathrm{C}$ until analyzed. All fermentations were carried out until no further $\mathrm{CO}_{2}$ fluctuations were observed. $\mathrm{pH}$ was not controlled by the addition of alkali during fermentation.

\subsection{Chemicals}

Chemicals were provided by Sigma Aldrich, excepting for galacturonic acid and glucose provided by Fluka Biochemical and glycerol provided by Fisher Scientific.

Commercially available enzyme solutions Depol ${ }^{\mathrm{TM}} 740 \mathrm{~L}$ (ferulic acid esterase), provided by Biocatalysts Ltd., Cefn Coed, Wales, U.K and Accellerase ${ }^{\circledR} 1500$ (endoglucanase), provided by Genencore were used. Both of them were added to the media at recommended doses. Declared activities were $36 \mathrm{U} / \mathrm{g}$ and 2200-2800 CMC U/g respectively $(1 \mathrm{CMC} \mathrm{U}=$ unit of activity liberates $1 \mu \mathrm{mol}$ of reducing sugars, expressed as glucose equivalents per minute at $50^{\circ} \mathrm{C}$ and $\left.\mathrm{pH} 4.8\right)$.

\subsection{Alcohol-Insoluble Residues (AIR) Preparation}

AIRs were prepared from pulp and residues prior to analysis for cell wall sugars. Wet fermented pineapple waste samples, after defrosting, were homogenized for $1 \mathrm{~min}$ at max speed in a Janke \& Kunnel, Ika-Werk Ultra-Turrax homogenizer at room temperature. $30 \mathrm{ml}$ of each sample were then poured into boiling ethanol, to obtain a final mixture with $\mathrm{EtOH}$ concentration of $85 \%(\mathrm{v} / \mathrm{v})$, considering the water content of the sample. $50 \mathrm{ml}$ of $70 \% \mathrm{EtOH}$ to wash down and collect any sample particles from the homogenizer were used. The insoluble residue remained after this treatment was recovered by vacuum filtration through a $5 \mu \mathrm{m}$ nylon filter NYBOLT using a Buchner funnel. After further 2 sequential extractions in boiling $85 \%$ ethanol $(\mathrm{v} / \mathrm{v})$ the residue was extracted in boiling absolute ethanol $(300 \mathrm{~mL}$ for $5 \mathrm{~min})$, then washed with cold absolute ethanol $(150 \mathrm{~mL})$. The final filtrate was dried by Büchi Rotary Evaporator at $40{ }^{\circ} \mathrm{C}$, recovered in water and tested for residual soluble sugars. The insoluble residue was washed with 2 volumes acetone and after removal by suction, dried to constant weight at $40^{\circ} \mathrm{C}$ (Waldron \& Selvendran, 1990; Mandalari et al., 2005).

\subsection{Moisture Determination}

The dry weights both of the fresh pineapple waste and fermentations samples, were calculated as steady weights after $2 \mathrm{~h}$ at $110^{\circ} \mathrm{C}$ using a Mettler PM 200 equipped with a Mettler LP16 IR balance.

\subsection{Sugar Determination}

Sugars were released from AIR samples by Saeman hydrolysis by sample dispersion in $72 \% \mathrm{H}_{2} \mathrm{SO}_{4}$ for $3 \mathrm{~h}$ at room temperature followed by hydrolysis in $1 \mathrm{M} \mathrm{H}_{2} \mathrm{SO}_{4}$ for $1 \mathrm{~h}$ at $100^{\circ} \mathrm{C}$.

Hydrolysates were derivatized as their alditol acetates and analyzed by GC using a Perkin-Elmer Autosystem XL (Perkin Elmer, Seer Green, UK), equipped with a flame ionization detection and a RTX-225 (Restek, Bellefonte, 
USA) column (Blakeney, Harris, Henry, \& Stone, 1983).

Analysis of supernatant fractions followed the same protocol, but starting from a hydrolysis in $1 \mathrm{M} \mathrm{H}_{2} \mathrm{SO}_{4}$.

The total uronic acid content in the sugar hydrolysates was spectrophotometrically determined using glucuronic acid as a standard following the method of Blumenkrantz and Asboe- Hansen (1973), modified by Rae et al. (1985).

All samples were analyzed in triplicate.

\subsection{Ethanol Determination}

Ethanol was quantified by HPLC.

$500 \mu 1$ samples of supernatant from fermented pineapple waste were centrifuged for 10 minutes at $500 \mathrm{rpm}$ and $20{ }^{\circ} \mathrm{C}$ in a 96 deep well plate using an Eppendorf Centrifuge $5810 \mathrm{R}$, then filtered through AcroPrep ${ }^{\mathrm{TM}} 0.2 \mu \mathrm{m}$ GHP Membrane 96 Well Filter Plates into a 96 deep well collection plate for further 10 minutes at the same speed.

After centrifugation plates were covered by a rubber lid and loaded directly onto a Series 200 LC instrument (Perkin Elmer, Seer Green, UK) equipped with a refractive index detector. Analyses were carried out using an Aminex HPX-87P column (Bio-Rad Laboratories Ltd, Hemel Hempstead, UK) with matching guard columns operating at $65{ }^{\circ} \mathrm{C}$ with ultrapure water at a flow rate of $0.6 \mathrm{~mL} / \mathrm{min}$ as mobile phase.

\subsection{Calculations}

Theoretical yield (TY) in this study was calculated as the max ethanol yield in relation to dry matter: $0.511 \mathrm{~g}$ alcohol per $1.0 \mathrm{~g}$ dry matter.

\section{Results}

\subsection{Direct Fermentation of the Blended Biomass Followed by Enzymes Addition (DF)}

Initially, ethanol production by $S$. cerevisiae NCYC 2826 using untreated blended biomass, with a dry matter content of $9.2 \%$, was investigated by batch culture in DF mode as described in section 2.3. Table 1 shows the composition of waste fiber at the beginning of the fermentation, before enzyme addition and at the end of the process. As shown in Table 1, at the beginning of the fermentation Glc and Xyl were the most abundant neutral monosaccharides in AIR PW residues, followed by Gal A, Ara, Gal and Man, with smaller proportions of Rha and Fuc. The main sugars in the soluble fraction (Figure 1) were Glc and Man; only small amounts of Gal A and Gal was detected.

Table 1. Monosaccharide compositions of pineapple waste cell walls. Fiber compositions at the time 0, after 12 hours and at the end of the process, for Direct Fermentation (DF), Separate Hydrolysis and Fermentation (SHF) and Simultaneous Saccharification and Fermentation (SSF)

\begin{tabular}{|c|c|c|c|c|c|c|c|c|c|c|c|c|c|c|c|c|c|c|c|c|}
\hline \multirow[b]{2}{*}{ Test } & \multirow[b]{2}{*}{ Hours } & \multirow{2}{*}{$\begin{array}{c}\text { residue } \\
(\%)\end{array}$} & \multicolumn{2}{|c|}{ total } & \multicolumn{2}{|c|}{ Rhamnose } & \multicolumn{2}{|c|}{ Fucose } & \multicolumn{2}{|c|}{ Arabinose } & \multicolumn{2}{|c|}{ Xylose } & \multicolumn{2}{|c|}{ Mannose } & \multicolumn{2}{|c|}{ Galactose } & \multicolumn{2}{|c|}{ Glucose } & \multicolumn{2}{|c|}{ Galacturonic acid } \\
\hline & & & M & SD & M & SD & $\mathrm{M}$ & SD & M & SD & $\mathrm{M}$ & $\mathrm{SD}$ & M & SD & M & SD & $\mathrm{M}$ & $\mathrm{SD}$ & M & SD \\
\hline & 0 & 3.9 & 657.1 & 30.6 & 3.0 & 0.3 & 2.5 & 0.2 & 57.0 & 2.1 & 224.8 & 9.8 & 22.3 & 1.1 & 34.8 & 4.2 & 251.7 & 25.1 & 60.9 & 3.7 \\
\hline \multirow[t]{3}{*}{ DF } & 12 & 3.7 & 642.5 & 29.8 & 2.8 & 0.2 & 1.5 & 0.2 & 59.8 & 0.2 & 214.7 & 14.9 & 24.1 & 1.7 & 35.8 & 1.6 & 239.3 & 16.6 & 64.5 & 1.5 \\
\hline & 48 & 1.7 & 528.6 & 17.8 & 2.7 & 0.3 & 0.9 & 0.1 & 31.4 & 4.2 & 242.3 & 15.8 & 21.7 & 3.0 & 18.2 & 2.7 & 173.2 & 10.6 & 38.1 & 4.9 \\
\hline & 0 & 3.2 & 660.1 & 53.5 & 1.5 & 0.1 & 1.1 & 0.1 & 62.6 & 2.7 & 246.4 & 16.0 & 16.5 & 2.0 & 36.0 & 3.1 & 235.4 & 20.2 & 60.4 & 8.9 \\
\hline \multirow[t]{3}{*}{ SHF } & 12 & 1.4 & 581.1 & 8.9 & 0.8 & 0.1 & 0.4 & 0.0 & 61.9 & 2.2 & 244.9 & 2.6 & 6.6 & 0.4 & 38.7 & 1.7 & 116.6 & 8.1 & 111.2 & 10.2 \\
\hline & 30 & 0.7 & 565.6 & 4.4 & 1.5 & 0.1 & 1.0 & 0.1 & 54.6 & 3.3 & 236.0 & 15.9 & 14.5 & 0.5 & 36.7 & 2.7 & 123.0 & 3.4 & 98.4 & 4.7 \\
\hline & 0 & 3.4 & 640.4 & 29.8 & 1.6 & 0.2 & 1.5 & 0.1 & 59.8 & 0.2 & 198.5 & 14.9 & 24.1 & 1.7 & 38.4 & 1.6 & 239.3 & 16.5 & 77.3 & 1.5 \\
\hline \multirow[t]{2}{*}{ SSF } & 12 & 1.2 & 432.4 & 37.3 & 1.2 & 0.2 & 0.6 & 0.1 & 35.0 & 4.2 & 174.9 & 33.6 & 28.7 & 1.9 & 21.5 & 2.5 & 133.7 & 13.3 & 36.7 & 5.8 \\
\hline & 30 & 0.8 & 375.4 & 12.3 & 1.2 & 0.1 & 0.7 & 0.1 & 32.4 & 2.3 & 97.3 & 6.3 & 29.7 & 2.5 & 22.6 & 1.9 & 85.2 & 1.6 & 106.3 & 12.5 \\
\hline
\end{tabular}

${ }^{\mathrm{a}}$ Expressed as $\mu \mathrm{g} / \mathrm{mg}$ anhydrous sugars in original sample.

Results are shown as mean value (M) and standard deviation $(\mathrm{SD})$; residue $(\%)=$ proportion of biomass recovered as alcohol insoluble residue (AIR). 
Table 2. Dry matter (\% FWt), fiber and soluble sugars (\% dry matter), EtOH yield, theoretical yield (TY) and pH for Direct Fermentation (DF), Separate Hydrolysis and Fermentation (SHF) and Simultaneous Saccharification and Fermentation (SSF)

\begin{tabular}{ccccccccccc}
\hline \multicolumn{3}{c}{ \% dry matter } & \% fiber in dry matter & $\%$ soluble sugars in dry matter & ethanol \%(V/V) & \multicolumn{2}{c}{$\mathrm{pH}$} \\
\hline test & initial & final & initial & final & initial & final & Amount & TY & initial & final \\
\hline DF & 9.2 & 3.1 & 27.8 & 5.4 & 57.8 & 4.7 & $3.4 \pm 0.2$ & 86 & 4.5 & 3.4 \\
SHF & 8.5 & 2.6 & 25 & 5.3 & 48.6 & 6.2 & $3.7 \pm 0.1$ & 89 & 5 & 3.3 \\
SSF & 9 & 2.7 & 23.9 & 3.4 & 42.2 & 7.5 & $3.9 \pm 0.1$ & 96 & 4.5 & 3.3 \\
\hline
\end{tabular}

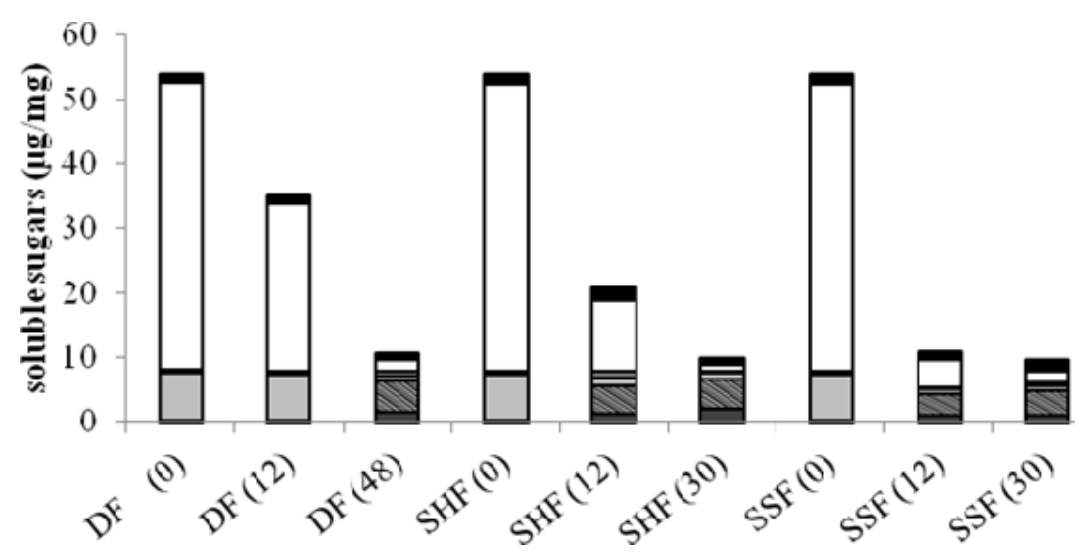

Figure 1. Soluble sugars in alcohol-soluble extracts of pineapple fermentation broths at time 0 , after 12 and at the end of the process, for Direct Fermentation (DF), Separate Hydrolysis and Fermentation (SHF) and Simultaneous Saccharification and Fermentation (SSF)

${ }^{\text {a }}$ Expressed as $\mu \mathrm{g} / \mathrm{mg}$ anhydrous sugars in original sample. GalA, black; Glu, white; Gal, dark gray; Man, light gray; Xyl, white with black lines; Ara, gray. 

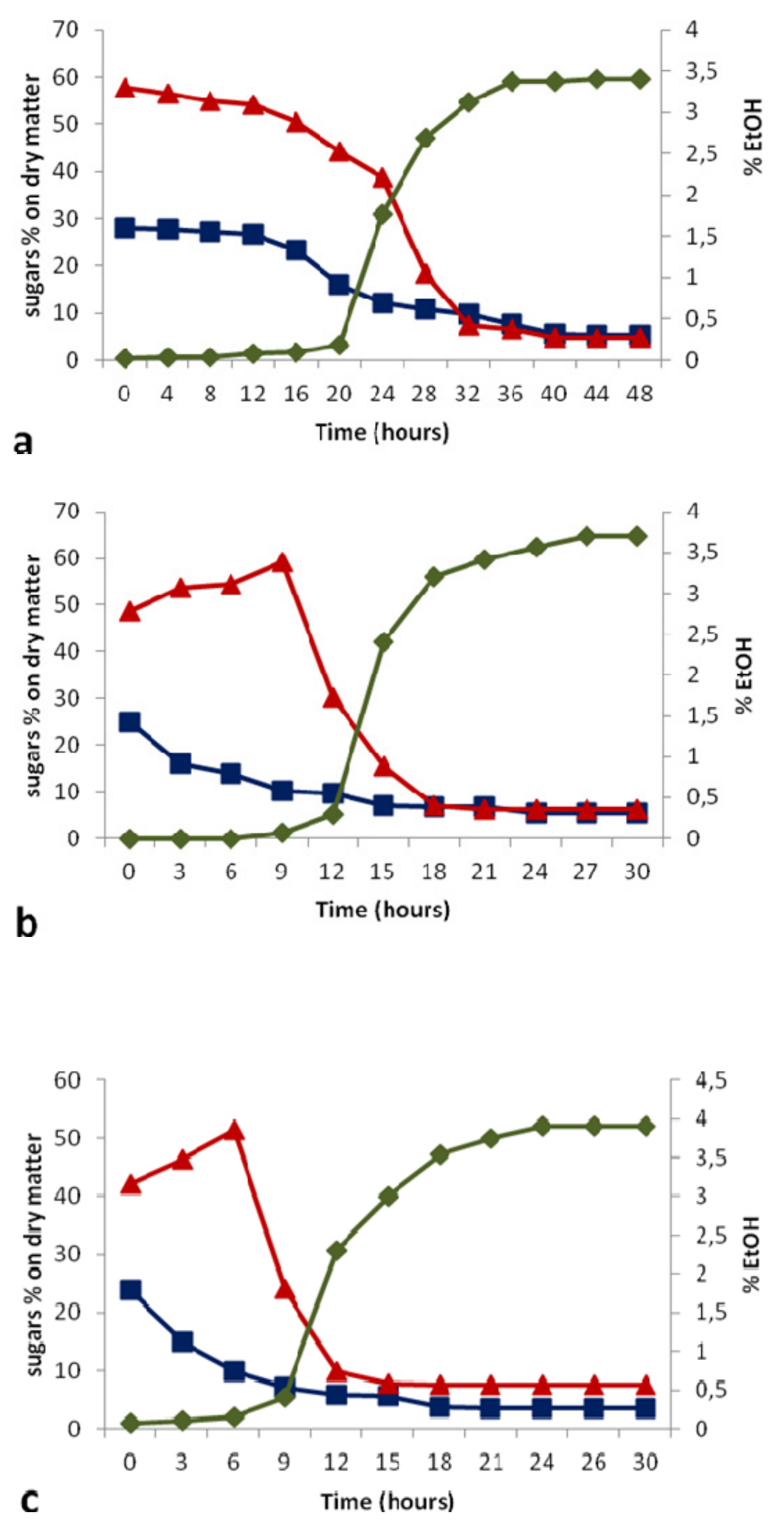

Figure 2. \% Fiber (square), \% soluble sugar (triangle) calculated on initial dry matter and \% EtOH (diamond) in pineapple waste fermented by Saccharomyces cerevisiae NCYC 2826 during: a) direct fermentation (DF), b) preliminary saccharification and consecutive fermentation of the blended wastes (SHF) and c) simultaneous saccharification and fermentation (SSF) 
Figure 2a shows the time course of ethanol production and corresponding decline in the levels of soluble and fiber-bound sugars. Sugars utilization by the yeast in the early phase of the culture was relatively slow and ethanol production very low. Sample collected before enzymes addition, after $12 \mathrm{~h}$ fermentation, showed a $0.07 \%$ ethanol concentration, with an insoluble sugar concentration slightly affected by yeast growth, whereas among the soluble sugars a $9 \%$ decrease in Glc was observed. The addition of cell-wall degrading enzymes to the substrate after $12 \mathrm{~h}$ caused a rapid sugars concentration decrease, followed by a corresponding increase in ethanol production. AIR residue \% decreased from 3.9 to 1.7 and the total amount of cell wall sugars decreased from $657.1 \mu \mathrm{g} / \mathrm{mg}$ to $528.6 \mu \mathrm{g} / \mathrm{mg}$. The Glc and Man in the soluble sugars fraction decreased by $63.7 \%$ and $5.3 \%$ respectively, whilst Xyl and Ara, Gal and Gal A increased reflecting their release from the cell walls, and the inability of the yeast to ferment them. Ethanol production reached $3.4 \%$ within $24 \mathrm{~h}$ of enzyme addition, reaching the $86 \%$ of the TY (Table 2). This ethanol concentration remained steady until fermentation was completed. The $\mathrm{pH}$ of the fermentation dropped down from 4.5 to 3.4 at the end of the process.

\subsection{Separate Hydrolysis and Fermentation of the Blended Wastes (SHF)}

Results concerning dry matter \%, fibres and soluble sugars for SHF process are reported in Table 2.

Initial dry matter of the material was $8.5 \%$. Figure $2 \mathrm{~b}$ shows ethanol production and sugar utilization by $S$. cerevisiae during SHF mode, described in section 2.3. The results show that the enzyme activity at the beginning of the process resulted in a decrease in the insoluble fraction and a concomitant increase in the soluble sugars. Initial monosaccharide compositions for the insoluble and soluble fractions were comparable with those found for DF mode (3.1 section), representing respectively $25 \%$ and $48.6 \%$ of initial dry matter. In keeping with these observations, enzymatic saccharification before yeast inoculation caused the AIR residue to decrease from $3.2 \%$ to $1.4 \%$, resulting in $15 \%$ fiber loss and $11 \%$ soluble sugars increase. The fiber $\%$ decreased to $10.17 \%$, followed by a soluble sugars increasing up to $59.26 \%$, before yeast addition. As shown in Table 1, by $12 \mathrm{~h}$ the AIR yield had decreased by over $50 \%$, and the insoluble sugars remaining had decreased from $660.1 \mu \mathrm{g} / \mathrm{mg}$ to $581.1 \mu \mathrm{g} / \mathrm{mg}$, due to solubilisation of Ara, Xyl, Man Gal Glu and Gal A; on the other hand soluble sugars showed a decrease in Glc and Man 31\% and 8\% respectively, presumably due to fermentation, and an increase in Xyl, Ara, Gal A and $\mathrm{Gal}$ from the fibre hydrolysis (Figure 1). At completion of fermentation, the AIR residue was $0.7 \%$ and total insoluble sugars concentration was $565.6 \mu \mathrm{g} / \mathrm{mg}$. The final dry matter content was $2.6 \%$ and fibers and soluble sugars \% dropped down to 5.36 and 6.2 respectively. The highest EY was up to $3.7 \%$, reaching $89 \%$ of the TY (Table 2). The $\mathrm{pH}$ recorded at the end of the process was 3.3.

\subsection{Simultaneous Saccharification and Fermentation (SSF)}

The initial fibers and soluble sugars were $23.9 \%$ and $42.2 \%$ respectively. Sugar composition was comparable with that above reported for DF mode in section 3.1 (Table 1). As shown in Figure 2c, saccharification started at $\mathrm{t}=0$ : soluble sugars increased reaching their highest concentration after 6 hours, at $51.54 \%$. By this time, the yeast was fermenting well and after this point the soluble sugars dropped rapidly whilst the alcohol began to increase up to a plateau of $4 \%$. By 21 hours ethanol production, as well as substrate utilization by the yeast, stopped as can be observed from the steady sugar and alcohol \%. Table 1 shows the monosaccharide composition in SSF sample at the beginning, after 12 hours fermentation and at the end of the process. In Figure 1 the soluble sugar composition is reported. By the end of the fermentation, Glc and Man concentrations were very low in comparison with the levels of Xyl, Ara and Gal A, as previously observed also for DF and SHF processes. Fiber and soluble sugars decreased during the process from $23.9 \%$ to $3.4 \%$ and $42.2 \%$ to $7.5 \%$ respectively. The highest EY was up to $3.9 \%$, reaching $96 \%$ of the TY (Table 2). At the end of the fermentation pH dropped down from 4.5 to 3.3 .

\section{Discussion}

The significant amount of carbohydrate-rich materials disposed of in the pineapple canneries makes this waste an interesting source for ethanol production. According with Abdullah and Mat (2008) and Huang et al. (2011), the main sugars, calculated on initial dry biomass, were glucose and xylose, followed by uronic acid, arabinose, galactose and mannose, with smaller amounts of rhamnose and fucose, revealing that pineapple wastes are primarily composed of celluloses, pectic substances and hemicelluloses. The presence of different polymeric substances in cell walls justify the need of a pre-treatment on this waste. DF gave rise to an EY of $0.07 \%$, due to soluble glucose utilization by yeast. After enzyme addition to the medium, the fiber started to be digested and the ethanol yield rose to $3.4 \%$, corresponding to a $86 \%$ of TY.

Tests carried out in SHF and SSF gave rise to $3.7 \%$ and $3.9 \%$ of EY, corresponding to $89 \%$ and $96 \%$ of TY respectively, calculated on a dry matter basis. 
Though the EY obtained appears rather low, due of course to the low sugar content, this could be attractive because TY, calculated on dry matter loss, was in a range around 90-96\%, making these wastes an excellent raw material for ethanol production by S. cerevisiae NCYC 2826, as compared with previous studies on juice or rotten pineapple (Ban-Koffi \& Han 1990; Nigam, 1999a; Nigam, 2000; Hossain \& Fazliny, 2010).

The preliminary tests reported in this paper show the importance of the enzymatic pretreatment of pineapple wastes to increase the sugar level of the mash for alcoholic fermentation. It should be pointed out that SHF and SSF show the same trend, both on fiber saccharification and on sugars utilization by $S$. cerevisiae. This means that the enzyme activity is not affected by the fermentation parameters used. In fact, previous saccharification used in SHF mode, at $50{ }^{\circ} \mathrm{C}, \mathrm{pH} 5$ and $500 \mathrm{rpm}$, was not followed by higher cell wall degradation in comparison with SSF mode, where enzymes and yeast were added together to the substrate at $30^{\circ} \mathrm{C}, \mathrm{pH} 4.5$ and $200 \mathrm{rpm}$. This facilitates the set up of fermentation processes based on the simultaneous addition of yeast culture and enzymes, to reduce both process time and total costs. In fact ethanol production in SSF started 3 hours before it did in SHF. Hence, SSF is probably the most convenient and suitable fermentation mode used in this study.

All samples of digested material were characterized by increases in soluble xylose, arabinose, galactose, galacturonic acid and glucose. This was due of course to the enzymatic saccharification of pineapple cell walls. Accellerase $^{\circledR} 1500$ activity was probably enhanced by Depol ${ }^{\mathrm{TM}} 740 \mathrm{~L}$ since, in accordance with the literature, pineapple cell walls are characterized by ferulic acid, esterified to glucuronoarabinoxylans (Smith \& Harris, 1995; Smith \& Harris, 2001). Enzymatic release of significant quantities of xylose and arabinose points to the use of mixed cultures and recombinant yeast, or in the development of robust strain that will simultaneously ferment hexose and pentose sugars for ethanol production. This would be expected to improve the final ethanol concentration and productivity, since a significant quantity of pentose sugars were left unutilized in hydrolysates fermented media.

All the fermentations carried out in this study were characterized by a dry matter loss of around $70 \%$. This means that $30 \%$ of substrate remained unutilized. This could be due to the $\mathrm{pH}$ decreasing during the fermentation period. In fact $\mathrm{pH}$ values appear to be steady in the range 3.3-3.5. The significant $\mathrm{pH}$ drop is probably caused by production of yeast catabolites and the release of D-galacturonic acid from pectin, having a pKa value 3.51 (Filippov, Shkolenko \& Kohn, 1978). The observed pH decrease could lead to a diminution on enzymatic activity and a consequent stop of fiber saccharification. Further tests, carried out with a strict $\mathrm{pH}$ control during the process, could improve dry matter utilization and consequently ethanol production.

Moreover, an EY improvement might also be achieved both by developing a more efficient pre-treatment method (mechanical and/or enzymatic) and by supplementing the substrate with different nitrogen sources to reduce the lag phase and increase yeast biomass.

\section{Acknowledgments}

The Authors acknowledge the "Dipartimento di Scienze dell'Ambiente, della Sicurezza, del Territorio, degli Alimenti e della Salute", University of Messina (I) and the Institute of Food Research Norwich (UK) (Institute Strategic Programme Grant BB/J004545/1 from BBSRC) for the support.

\section{References}

Abdullah. (2007). Solid and liquid pineapple waste utilization for lactic acid fermentation using Lactobacillus delbrueckii. Reaktor, 11(1), 50-52.

Abdullah \& Mat, H. (2008). Characterisation of solid and liquid pineapple waste. Reaktor, 12(1), 48-52.

Banik, S., Nag, D., \& Debnath, S. (2011). Utilization of pineapple leaf agro-waste for extraction of fibre and the residual biomass for vermicompoting. Indian Journal of Fibre \& Textile Reasearch, 36(2), 172-177.

Ban-Koffi, L., \& Han, Y. W. (1990). Alcohol production from pineapple waste. World Journal of Microbiology and Biotechnology, 6(3), 281-284. http://dx.doi.org/10.1007/BF01201297

Blakeney, A. B., Harris, P. J., Henry, R. J., \& Stone, B. A. (1983). A simple and rapid preparation of alditol acetates for monosaccharide analysis. Carbohydrate Research, 113(2), 291-299. http://dx.doi.org/10.1016/0008-6215(83)88244-5

Blumenkrantz, N., \& Asboe-Hansen, G. (1973). New method for quantitative determination of uronic acids. Analytical Biochemestry, 54(2), 484-489. http://dx.doi.org/10.1016/0003-2697(73)90377-1

Busairi, M. A. (2008). Conversion of pineapple juice waste into lactic acid in batch and fed - batch fermentation systems. Reaktor, 12(2), 98-101. 
Dacera, D. D. M., Babel, S. \& Parkpian, P. (2009). Potential for land application of contaminated sewage sludge treated with fermentaed liquid from pineapple wastes. Journal of Hazardous Materials, 167(1-3), 866-872. http://dx.doi.org/10.1016/j.jhazmat.2009.01.064

Dhanasekaran, D., Lawanya, S., Saha, S., Thajuddin, N., \& Panneerselvam, A. (2011). Production of single cell protein from pineapple waste using yeast. Innovative Romanian Food Biotechnology, 8(3), 26-32.

FAO. (2009). Food Outlook. Global Market Analysis. Global Information and Early Warning System, 2(2), $1-103$.

Farrell, A. E., Plevin, R. J., Turner, B. T., Jones, A. D., O’Hare, M., \& Kammen, D. M. (2006). Ethanol can contribute to energy and environmental goals. Science, 311(5760), 506-508. http://dx.doi.org/10.1126/science.1121416

Field, C. B., Campbell, J. E., \& Lobell, D. B. (2008). Biomass energy: The scale of the potential resource. Trends in Ecology and Evolution, 23(2), 65-72. http://dx.doi.org/10.1016/j.tree.2007.12.001

Filippov, M. P, Shkolenko, G. A., \& Kohn, R. (1978). Determination of the esterification degree of the pectin of different origin and composition by the method of infrared spectroscopy. Chemicke Zvesti., 32(1), 218-222.

Galbe, M., \& Zacchi, G. (2002). A review of the production of ethanol from softwood. Applied Microbiology and Biotechnology, 59(6), 618-628. http://dx.doi.org/10.1007/s00253-002-1058-9

Galbe, M., \& Zacchi, G. (2007). Pretreatment of lignocellulosic materials for efficient bioethanol production. Advances in Biochemical Engineering/Biotechnology, 108(1), 41-65. http://dx.doi.org/10.1007/10_2007_070

Goh, C. S., Tan, K. T., Lee, K. T. \& Bhatia, S. (2010). Bio-ethanol from lignocellulose: Status perspectives and challenges in Malaysia. Bioresource Technology, 101(13), 4834-4841. http://dx.doi.org/10.1016/j.biortech.2009.08.080

Hahn-Hägerdal, B., Galbe, M., Gorwa-Grauslund, M. F., Lidén, G., \& Zacchi, G. (2006). Bio-ethanol - the fuel of tomorrow from the residues of today. Trends in Biotechnology, 24(12), 549-556. http://dx.doi.org/10.1016/j.tibtech.2006.10.004

Hebbar, H. U., Sumana, B., \& Raghavarao, K. S. M. S. (2008). Use of reverse micellar systems for the extraction and purification of bromelain from pineapple wastes. Bioresource Technology, 99(11), 4896-4902. http://dx.doi.org/10.1016/j.biortech.2007.09.038

Himmel, M. E., Ding, S. Y., Johnson, D. K., Adney, W. S., Nimlos, M. R., Brady, J. W., \& Foust, T. D. (2007). Biomass recalcitrance: Engineering plants and enzymes for biofuels production. Science, 315(5813), 804-807. http://dx.doi.org/10.1126/science. 1137016

Hossain, A. B. M. S., \& Fazliny, A. R. (2010). Creation of alternative energy by bio-ethanol production from pineapple waste and the usage of its properties for engine. African Journal of Microbiology Research, 4(9), 813-819.

Hu, G., Heitmann, J. A., \& Rojas, O. J. (2008). Feedstock pretreatment strategies for producing ethanol from wood, bark, and forest residues. BioResources, 3(1), 270-294.

Huang, Y. L., Chow, C. J., \& Fang, Y. J. (2011). Preparation and Physicochemical Properties of fiber-rich fraction from pineapple peels as a potential ingredient. Journal of Food and Drug Analysis, 19(3), 318-323.

Jamal, P., Fahrurrazi, T. M., \& Zahangir A. M. (2009). Optimization of media composition for the production of bioprotein from pineapple skins by liquid-state bioconversion. Journal of Applied Sciences, 9(17), 3104-3109. http://dx.doi.org/10.3923/jas.2009.3104.3109

Larrauri, J. A., Ruperez, P., \& Calixto, F. S. (1997). Pineapple shell as a source of dietary fiber with associated polyphenols. Journal of Agricultural and Food Chemistry, 45(10), 4028-4031. http://dx.doi.org/10.1021/j9970450j

Lin, Y., \& Tanaka, S. (2006). Ethanol fermentation from biomass resources: current state and prospects. Applied Microbiology and Biotechnology, 69(6), 627-642. http://dx.doi.org/10.1007/s00253-005-0229-x

Mandalari, G., Faulds, C. B., Sancho, A. I., Saija, A., Bisignano, G., Lo Curto, R., \& Waldron, K. W. (2005). Fractionation and characterisation of arabinoxylans from brewers spent grain and wheat bran. Journal of Cereal Science, 42(2), 205-212. http://dx.doi.org/10.1016/j.jcs.2005.03.001

Merino, S. T., \& Cherry, J. (2007). Progress and challenges in enzyme development for biomass utilization. 
Advances in Biochemical Engineering/Biotechnology, $\quad$ 108(1), http://dx.doi.org/10.1007/10_2007_066

Mosier, N., Wyman, C., Dale, B., Elander, R., Lee, Y. Y., Holtzapple, M. \& Ladisch, M. R. (2005). Features of Promising Technologies for Pretreatment of Lignocellulosic Biomass. Bioresource Technology, 96(6), 673-686. http://dx.doi.org/10.1016/j.biortech.2004.06.025

Nigam, J. N. (1999a). Continuous ethanol production from pineapple cannery waste. Journal of Biotechnology, 72(1), 197-202. http://dx.doi.org/10.1016/S0168-1656(99)00106-6

Nigam, J. N. (1999b). Continuous cultivation of the yeast Candida utilis at different dilution rates on pineapple cannery waste. World Journal of Microbiology \& Biotechnology, 15(1), 115-117. http://dx.doi.org/10.1023/A:1008870228213

Nigam, J. N. (2000). Continuous ethanol production from pineapple cannery waste using immobilized yeast cells. Journal of Biotechnology, 80(2), 189-193. http://dx.doi.org/10.1016/S0168-1656(00)00246-7

Philippidis, G. P., Smith, T. K., \& Wyman, C. E. (1993). Study of the enzymatic hydrolysis of cellulose for production of fuel ethanol by the simultaneous saccharification and fermentation process. Biotechnology and Bioengineering, 41(9), 846-853. http://dx.doi.org/10.1002/bit.260410903

Rae, A. L., Harris, P. J., Bacic, A., \& Clarke, A. E. (1985). Composition of the cell walls of Nicotiana alata Link et Otto pollen tubes. Planta, 166(1), 128-133. http://dx.doi.org/10.1007/BF00397395

Raji, Y. O., Jibril, M., Misau, I. M., \& Danjuma, B. Y. (2012). Production of vinegar from pineapple peel. International journal of advanced scientific research and technology, 3(2), 656-666.

Sakai, S., Tsuchida, Y., Nakamoto, H., Okino, S., Ichihashi, O., Kawaguchi, H., ... Yukawa, H. (2007). Effect of lignocellulose-derived inhibitors on growth of and ethanol production by growth arrested Corynebacterium glutamicum R. Applied and Environmental Microbiology., 73(7), $2349-53$. http://dx.doi.org/10.1128/AEM.02880-06

Searchinger, T., Heimlich, R., Houghton, R. A., Dong, F., Elobeid, A., Fabiosa, J., .. Tun-Hsiang, Y. (2008). Use of U.S. croplands for biofuels increases greenhouse gases through emissions from land-use change. Science, 319(5867), 1238-1240. http://dx.doi.org/10.1126/science.1151861

Smith, B. G. \& Harris, P. J. (1995). Polysaccharide composition of unlignified cell walls of pineapple [Ananas comosus (L.) Merr.] fruit. Plant Physiology, 107(4), 1399-1409. http://dx.doi.org/10.1104/pp.107.4.1399

Smith, B. G., \& Harris, P. J. (2001). Ferulic acid is esterified to glucuronoarabinoxylans in pineapple cell walls. Phytochemistry, 56(5), 513-519. http://dx.doi.org/10.1016/S0031-9422(00)00401-5

Soderstrom, J., Galbe, M., \& Zacchi, G. (2005). Separate versus simultaneous saccharification and fermentation of two-step steam pretreated softwood for ethanol production. Journal of Wood Chemistry and Technology, 25(3), 187-202. http://dx.doi.org/10.1080/02773810500191807

Sun, Y.. \& Cheng, J. (2002). Hydrolysis of lignocellulosic materials for ethanol production: a review. Bioresource Technology, 83(1), 1-11. http://dx.doi.org/10.1016/S0960-8524(01)00212-7

Takagi, M., Abe, S., Suzuki, S., Emert, G. H., \& Yata, N. (1977). A method for production of alcohol direct from cellulose using cellulase and yeast. In Proceedings of the Bioconversion of Cellulosic Substances into Energy, Chemicals and Microbial Protein (pp. 551-571). Symposium IIT (New Delhi, India).

Tengborg, C., Galbe, M., \& Zacchi, G. (2001). Reduced inhibition of enzymatic hydrolysis of steam pretreated softwood. Enzyme and Microbial Technology, 28(9-10), 835-844. http://dx.doi.org/10.1016/S0141-0229(01)00342-8

Waldron, K. W., \& Selvendran, R. R. (1990). Composition of the cell walls of different asparagus (Asparagus $\begin{array}{lllll}\text { officinalis) } \quad \text { tissues. } & \text { Physiologia } & \text { Plantarum, } & \text { 50(4), }\end{array}$ http://dx.doi.org/10.1111/j.1399-3054.1990.tb05680.x

Wooley, R., Ruth, M., Glassner, D., \& Sheehan, J. (1999). Process Design and Costing of Bioethanol Technology: A Tool for Determining the Status and Direction of Research and Development. Biotechnology Progress, 15(5), 794-803. http://dx.doi.org/10.1021/bp990107u

Wright, J. D., Wyman, C. E., \& Grohmann, K. (1988). Simultaneous saccharification and fermentation of lignocellulose: process evaluation. Applied Biochemistry and Biotechnology, 18(1), $75-90$. http://dx.doi.org/10.1007/BF02930818 
Yu, Z., \& Zhang, H. (2004). Ethanol fermentation of acid-hydrolyzed cellulosic pyrolysate with Saccharomyces cerevisiae. Bioresource Technology, 93(2), 199-204. http://dx.doi.org/10.1016/j.biortech.2003.09.016

\section{Copyrights}

Copyright for this article is retained by the author(s), with first publication rights granted to the journal.

This is an open-access article distributed under the terms and conditions of the Creative Commons Attribution license (http://creativecommons.org/licenses/by/3.0/). 